\title{
Effects of flaxseed encapsulation on biohydrogenation of polyunsaturated fatty acids by ruminal microorganisms: feedlot performance, carcass quality, and tissue fatty acid composition ${ }^{1}$
}

\author{
C. A. Alvarado-Gilis, *2 C. C. Aperce,* K. A. Miller,* \\ C. L. Van Bibber-Krueger, * D. Klamfoth, $\dagger$ and J. S. Drouillard*3 \\ *Department of Animal Sciences and Industry, Kansas State University, Manhattan 66506; \\ and †Lhoist North America, Fort Worth, TX 76107
}

\begin{abstract}
The objective of this study was to evaluate the efficacy of protecting PUFA within ground flaxseed against ruminal biohydrogenation by encapsulating them in a matrix consisting of a 1:1 blend of ground flaxseed and dolomitic lime hydrate (L-Flaxseed). Crossbreed heifers $(n=462,346 \pm 19 \mathrm{~kg})$ were blocked by weight and randomly assigned to pens. Pens were assigned to 1 of 6 dietary treatments in a randomized complete block design. Treatment 1 consisted of a combination of $54.6 \%$ steam-flaked corn (SFC), 30.0\% wet corn gluten feed, $8.0 \%$ roughage, and supplement ( $0 \%$ flaxseed). In treatments 2 and 3 , a proportion of SFC was replaced with 3 and $6 \%$ flaxseed, respectively; in treatments 4,5 , and $6, \mathrm{SFC}$ was replaced with 2,4 , or $6 \%$ L-Flaxseed, respectively. Cattle were fed for 140 or $168 \mathrm{~d}$ and then harvested in a commercial abattoir where carcass data were collected. Approximately $24 \mathrm{~h}$ after harvest, carcasses were evaluated for 12th-rib fat thickness, KPH, LM area, marbling score, and USDA yield and quality grades. Samples of LM were also obtained for determination of long-chain fatty acid profiles. Cattle that were fed diets with 4 and 6\% L-Flaxseed consumed less feed than other treatments $(P<0.05)$, which adversely affected
\end{abstract}

ADG. Compared with cattle fed $0 \%$ flaxseed, cattle in these treatments had lower final BW (18 and $45 \mathrm{~kg}$ less for the 4 and 6\% L-Flaxseed treatments, respectively), less ADG (0.16 and $0.48 \mathrm{~kg} /$ day less for the 4 and $6 \%$ L-Flaxseed treatments, respectively), and lower carcass weights, dressing percentages, LM areas, backfat thicknesses, and marbling scores $(P<0.05)$. The addition of flaxseed or $2 \%$ L-Flaxseed did not affect performance or carcass traits $(P>0.05)$. Supplementation with flaxseed increased $(P<0.05)$ the concentration of $\alpha$-linolenic acid (ALA) in meat $(0.173,0.482,0.743$ $\mathrm{mg} / \mathrm{g}$ for 0,3 , and $6 \%$ flaxseed, respectively). Furthermore, proportionate increases in the ALA content of muscle tissue were $47 \%$ greater when flaxseed was encapsulated within the dolomitic lime hydrate matrix (0.288, 0.433, $0.592 \mathrm{mg} / \mathrm{g}$ for 2, 4, and 6\% L-Flaxseed, respectively). Both products showed a linear response in ALA concentration $\left(R^{2}>99 \%\right.$; increases for Flaxseed and L-Flaxseed of 0.095 and $0.140 \mathrm{mg}$ of ALA $/ \mathrm{g}$ of tissue for each percentage of flaxseed added). This study indicates that a matrix consisting of dolomitic lime hydrate is an effective barrier to ruminal biohydrogenation of PUFA; however, adverse effects on DMI limit the amounts that can be fed.

Key words: encapsulation, matrix, omega-3 fatty acids

(C) 2015 American Society of Animal Science. All rights reserved.

\footnotetext{
${ }^{1}$ Contribution number 14-338-J from the Kansas Agricultural Experiment Station, Manhattan, KS.

${ }^{2}$ Present address: Institute of Animal Production, Faculty of Agricultural Science, Universidad Austral de Chile, Valdivia 5110566, Chile.

${ }^{3}$ Corresponding author: jdrouill@ksu.edu

Received April 6, 2015.

Accepted June 26, 2015.
}

J. Anim. Sci. 2015.93:4368-4376 doi:10.2527/jas2015-9171

\section{INTRODUCTION}

Omega-3 fatty acids (n-3 FA) are essential nutrients for humans, but human dietary intake of these nutrients is often inadequate due to low consumption of $n-3$ FA-rich foods such as fish, walnuts, and flaxseed (Papanikolaou et al., 2014). The per capita con- 
sumption of red meats is, in contrast, relatively high but provides only small amounts of $n-3$ FA (Daniel et al., 2011). Feeding cattle diets containing $n-3$ FA has consistently increased the proportion of these desirable fats in beef (Drouillard et al., 2004). Unfortunately, the proportions of dietary $n-3$ FA that are actually deposited into beef tissues is relatively low because rumen microorganisms extensively biohydrogenate unsaturated $n-3$ FA to the saturated fats characteristic of beef fat (Montgomery et al., 2008). Encapsulation of fats has been proposed as a method for improving transfer efficiency of $n$ - 3 FA into beef tissues (Alvarado-Gilis et al., 2015). Encapsulation processes consist of applying a protective barrier to the surface of fats or fat-containing feeds, which theoretically decreases their susceptibility to microbial biohydrogenation. The encapsulating matrix is created by mixing feed particles that are to be protected with a suitable matrix material that is resistant to microbial digestion and subsequently forming prills with the mixture. In contrast with encapsulation, when the matrix incurs physical damage, exposure of the core material is confined to the broken surface, and the remainder of the matrix retains its ruminal stability.

The hypothesis of the study was that encapsulation of ground flaxseed would protect $n-3$ FA against rumen biohydrogenation, and the objectives were to compare feedlot performance, carcass characteristics, blood plasma fatty acid profiles, and meat lipids of cattle fed traditional finishing diets to those supplemented with ground flaxseed or ground flaxseed that has been that has been co-prilled with dolomitic lime hydrate forming a protective matrix.

\section{MATERIALS AND METHODS}

Procedures in this study were approved by the Kansas State University Institutional Animal Care and Use Committee protocol number 2315.

\section{Animals and Diets}

Crossbred heifers $(n=462, \mathrm{BW}=345.9 \pm 19.9$ $\mathrm{kg}$ ) were blocked by weight and randomly assigned to pens, and pens were assigned to dietary treatments (11 replicates). This experiment included 6 treatment groups in a randomized complete block design. Treatment 1 ( $0 \%$ flaxseed) consisted of animals fed a finishing diet (Table 1) containing a combination of steam-flaked corn, wet corn gluten feed, and roughage, supplemented with vitamins $A$ and $E$, macro minerals (calcium, potassium), inorganic trace minerals ( $\mathrm{Na}$, $\mathrm{Co}, \mathrm{Cu}, \mathrm{I}, \mathrm{Mn}, \mathrm{Se}$, and $\mathrm{Zn}$ ), monensin, and tylosin (Elanco Animal Health, Greenfield, IN). Treatments
Table 1. Composition of experimental diets containing 0,3 , and $6 \%$ ground flaxseed (Flaxseed) or 2, 4 , and $6 \%$ of a $1: 1$ blend of dolomitic lime hydrate and ground flaxseed formed into a prilled matrix (L-Flaxseed)

\begin{tabular}{|c|c|c|c|c|c|c|}
\hline \multirow[b]{2}{*}{ Item, $\%$ of DM } & \multicolumn{3}{|c|}{ Flaxseed } & \multicolumn{3}{|c|}{ L-Flaxseed } \\
\hline & $0 \%$ & $3 \%$ & $6 \%$ & $2 \%$ & $4 \%$ & $6 \%$ \\
\hline \multicolumn{7}{|l|}{ Ingredients } \\
\hline $\begin{array}{l}\text { Steam-flaked } \\
\text { corn }\end{array}$ & 54.58 & 52.47 & 50.49 & 53.47 & 52.37 & 51.26 \\
\hline $\begin{array}{l}\text { Wet corn gluten } \\
\text { feed }\end{array}$ & 30.00 & 30.00 & 30.00 & 30.00 & 30.00 & 30.00 \\
\hline Corn silage & 5.00 & 5.00 & 5.00 & 5.00 & 5.00 & 5.00 \\
\hline Wheat straw & 3.00 & 3.00 & 3.00 & 3.00 & 3.00 & 3.00 \\
\hline Soybean meal & 1.66 & 0.84 & - & 1.46 & 1.26 & 1.06 \\
\hline Ground flaxseed & - & 3.00 & 6.00 & - & - & - \\
\hline L-Flaxseed & - & - & - & 2.00 & 4.00 & 6.00 \\
\hline Supplement ${ }^{1}$ & 5.76 & 5.69 & 5.51 & 5.07 & 4.37 & 3.68 \\
\hline \multicolumn{7}{|c|}{ Calculated composition } \\
\hline $\mathrm{DM}$ & 68.36 & 68.52 & 68.57 & 68.42 & 68.48 & 68.54 \\
\hline $\mathrm{CP}$ & 14.00 & 14.00 & 14.00 & 14.00 & 14.00 & 14.00 \\
\hline $\mathrm{P}$ & 0.48 & 0.48 & 0.49 & 0.47 & 0.47 & 0.47 \\
\hline $\mathrm{Ca}$ & 0.88 & 0.88 & 0.88 & 0.88 & 0.88 & 0.88 \\
\hline Total fat & 3.59 & 4.65 & 5.72 & 3.87 & 4.15 & 4.42 \\
\hline $\mathrm{NDF}$ & 20.47 & 20.61 & 20.75 & 20.36 & 20.24 & 20.13 \\
\hline NEm & 0.94 & 0.96 & 0.97 & 0.93 & 0.92 & 0.90 \\
\hline $\mathrm{NEg}$ & 0.65 & 0.66 & 0.67 & 0.64 & 0.63 & 0.62 \\
\hline
\end{tabular}

${ }^{1}$ Formulated to provide $300 \mathrm{mg} / \mathrm{d}$ monensin (Elanco Animal Health, Greenfield, IN), 2,200 IU/kg vitamin A, $22 \mathrm{IU} / \mathrm{kg}$ vitamin E, $0.3 \%$ salt, $0.7 \% \mathrm{Ca}, 0.7 \% \mathrm{~K}, 0.1 \mathrm{mg} / \mathrm{kg}$ added $\mathrm{Co}, 10$ added $\mathrm{mg} / \mathrm{kg} \mathrm{Cu}, 0.6 \mathrm{mg} / \mathrm{kg} \mathrm{I}$, $60 \mathrm{mg} / \mathrm{kg} \mathrm{Mn}, 0.25 \mathrm{mg} / \mathrm{kg}$ added Se, and $60 \mathrm{mg} / \mathrm{kg}$ added $\mathrm{Zn}$ in the total diet on a $100 \%$ DM basis.

2 and 3 included 3 and $6 \%$ ground flaxseed, respectively (Flaxseed treatments). Treatments 4, 5, and 6 contained 2, 4, or $6 \%$ of a prilled mixture of ground flaxseed and dolomitic lime hydrate (L-Flaxseed treatments) that served as a protective barrier against biohydrogenation. Total fat and fatty acid composition are presented in Table 2. Dolomitic lime was blended with flaxseed, water was added, and the mix was subjected to mixing in a high-speed turbulizer to form densified prills, which were then dried to a final DM of approximately $98 \%$. Cattle were fed once daily with ad libitum access to feed and water. Heifers were implanted (Component TE-200; Zoetis Inc., Florham Park, NJ), dewormed (Dectomax; Zoetis Inc.), and vaccinated against common viral and clostridial diseases (Ultrabac 7 and Bovi-Shield Gold; Zoetis Inc.).

\section{Sampling Procedures and Harvest Data Collection}

Animals were weighed approximately every 28 $\mathrm{d}$ for the duration of the experiment. The initial and final weights for each pen were used for additional 
Table 2. Total lipid contents (chloroform/methanol extraction) and fatty acid composition of Flaxseed and L-Flaxseed

\begin{tabular}{lcc}
\hline \hline Item & Flaxseed & L-Flaxseed \\
\hline Total fat, \% of DM & 37.8 & 20.1 \\
Fatty acids, \% of total fatty acids & \\
C12:0 & 0.40 & 0.21 \\
C15:0 & 0.02 & 0.03 \\
C16:0 & 5.13 & 6.39 \\
C16:1 & 0.07 & 0.09 \\
C17:0 & 0.06 & 0.07 \\
C18:0 & 3.89 & 4.68 \\
C18:1 n-9 & 20.77 & 22.72 \\
C18:2 $n-6$ & 15.55 & 16.35 \\
C20:0 & 0.16 & 0.19 \\
C18:3 n-3 & 53.26 & 48.32 \\
C20:1 & 0.15 & 0.24 \\
C21:0 & 0.02 & 0.14 \\
C20:2 & 0.10 & 0.07 \\
C22:0 & 0.18 & 0.20 \\
C24:0 & 0.13 & 0.19 \\
\hline
\end{tabular}

estimations (i.e., daily gain and feed to gain). At the beginning of the experiment and $29 \mathrm{~d}$ later, blood samples $(8 \mathrm{~mL})$ were collected from the jugular vein of each animal using heparinized vacuum tubes (BD, Franklin Lakes, NJ). Tubes were immediately placed in ice and centrifuged $(3,200 \times g$ for $20 \mathrm{~min}$ at room temperature), and plasma was collected and frozen for subsequent analysis of long-chain fatty acids (LCFA) by gas chromatography. Starting $23 \mathrm{~d}$ before harvest, zilpaterol hydrochloride (Zilmax; Intervet/ScheringPlough Animal Health, De Soto, KS) was added to the diet for $20 \mathrm{~d}$. The 6 heaviest pens from each treatment were harvested at a commercial abattoir on d 140, and the remaining pens were harvested at the same location on d 168. Hot carcass weight and liver abscesses data were collected at slaughter. After a $24-\mathrm{h}$ chill period, carcasses were evaluated for fat thickness over the 12th rib, KPH, LM area, marbling score, and USDA yield and quality grades. Entire loins from 1 side of each carcass were collected, transported in a refrigerated truck to the Kansas State University Meat Laboratory, refrigerated overnight at $0 \pm 2^{\circ} \mathrm{C}$, subsampled the next day, and kept frozen for further analysis.

On animal weighing days, unconsumed feed remaining in feed bunks was measured for each pen, and DMI was estimated using the as-fed deliveries and actual feedstuff DM values minus the amount of unconsumed DM. Daily gain was calculated as kilograms of gain on a shrunk basis (4\%). Feed efficiency was calculated as kilograms of gain per kilogram of DM consumed.

\section{Analyses of Plasma Fatty Acids}

One milliliter of plasma was freeze-dried and combined with $1 \mathrm{~mL}$ benzene containing methyl tridecanoate as the internal standard $(400 \mu \mathrm{g} / \mathrm{mL}$ of benzene, Fluka 91558; Sigma-Aldrich, St. Louis, MO) and $4 \mathrm{~mL}$ of a boron trifluoride-methanol solution. Tubes were incubated at $60^{\circ} \mathrm{C}$ for $60 \mathrm{~min}$ and cooled to room temperature before the addition of $1 \mathrm{~mL}$ hexane and 4 $\mathrm{mL} \mathrm{H}_{2} \mathrm{O}$. Finally, tubes were vortexed and centrifuged at $1,000 \times g$ for $5 \mathrm{~min}$ at room temperature before the organic solvent layer ( 1 to $2 \mathrm{~mL}$ ) was collected to be analyzed via gas chromatography. An Agilent gas chromatograph (model 7890A; Agilent, Santa Clara, CA) equipped with an HP-88 J\&W Agilent GC capillary column ( $30-\mathrm{m}$ by $0.25-\mathrm{mm}$ by $0.20-\mu \mathrm{m}$ film) was used for the analysis. The injection temperature was $250^{\circ} \mathrm{C}$, and the split ratio was 1:100. The flame-ionization detector was set at $280^{\circ} \mathrm{C}$, using $\mathrm{H}(35 \mathrm{~mL} / \mathrm{min})$, air (400 $\mathrm{mL} / \mathrm{min})$, makeup He (25 mL/min), and He carrier gas at constant flow $(0.91 \mathrm{~mL} / \mathrm{min})$. The oven temperature program was set as follows: the initial temperature was $80^{\circ} \mathrm{C}$, held $1 \mathrm{~min}$, increased $14^{\circ} \mathrm{C} / \mathrm{min}$ to $240^{\circ} \mathrm{C}$, and held 3 min. Supelco 37 Component FAME Mix (47885U Supelco; Sigma-Aldrich) was used as the standard.

\section{Muscle Sample Analyses}

The LCFA profiles were analyzed according to the procedure of Sukhija and Palmquist (1988). Briefly, 40 to $50 \mathrm{~g}$ of loin samples from the 12th rib were freezedried and ground, and about $0.2 \mathrm{~g}$ of dry sample was mixed with $2 \mathrm{~mL}$ of benzene containing methyl tridecanoate as the internal standard $(2 \mathrm{mg} / \mathrm{mL}$ of benzene, Fluka 91558) and $5 \mathrm{~mL}$ methanolic- $\mathrm{HCl}$, then flushed with $\mathrm{N}$. Tubes were then capped, vortexed, heated for $2 \mathrm{~h}$ at $70^{\circ} \mathrm{C}$, and vortexed every $30 \mathrm{~min}$ during heating. Tubes were cooled to room temperature, mixed with 5 $\mathrm{mL} 6 \% \mathrm{~K}_{2} \mathrm{CO}_{3}$ and $2 \mathrm{~mL}$ benzene, vortexed, and centrifuged at $500 \times g$ for $5 \mathrm{~min}$ at room temperature. The organic solvent layer was then analyzed by gas chromatography as previously described for plasma LCFA.

\section{Statistical Analyses}

Continuous data (LCFA, growth performance, and carcass characteristics) were analyzed using the MIXED procedure of SAS (version 9.2; SAS Inst. Inc., Cary, NC). Categorical data (USDA quality grade and liver abscesses) were analyzed using the GLIMMIX procedure of SAS. In both models, pens were the experimental units, diet the fixed effect, and block (the animal initial weight) and slaughter day were random effects. Treatment means were separated using the LSMEANS statement and the PDIFF option of SAS. 
Table 3. Fatty acid concentrations in plasma of heifers fed 0,3 , and $6 \%$ ground flaxseed (Flaxseed) or 2, 4, and $6 \%$ of a 1:1 blend of dolomitic lime hydrate and ground flaxseed formed into a prilled matrix (L-Flaxseed)

\begin{tabular}{|c|c|c|c|c|c|c|c|c|}
\hline \multirow[b]{2}{*}{ Fatty acid, $\mu \mathrm{g} / \mathrm{mL}$} & \multicolumn{3}{|c|}{ Flaxseed } & \multicolumn{3}{|c|}{ L-Flaxseed } & \multirow[b]{2}{*}{ SEM } & \multirow[b]{2}{*}{$P$-value ${ }^{1}$} \\
\hline & $0 \%$ & $3 \%$ & $6 \%$ & $2 \%$ & $4 \%$ & $6 \%$ & & \\
\hline \multicolumn{9}{|l|}{ Day 0} \\
\hline $\mathrm{C} 16: 0$ & 324.9 & 334.9 & 319.4 & 298.5 & 315.3 & 316.4 & 11.92 & 0.18 \\
\hline C18:0 & 418.2 & 440.6 & 423.9 & 392.8 & 423.8 & 423.1 & 15.80 & 0.21 \\
\hline C18:1 cis-9 & 247.9 & 245.5 & 252.3 & 223.1 & 241.7 & 240.7 & 13.13 & 0.33 \\
\hline C18:2 cis-9, cis-12 & 1,342 & 1,398 & 1,303 & 1,293 & 1,328 & 1,326 & 62.43 & 0.65 \\
\hline $\mathrm{C} 18: 3 n-6$ & 10.81 & 11.46 & 10.39 & 9.77 & 11.51 & 10.97 & 1.34 & 0.94 \\
\hline $\mathrm{C} 18: 3 n-3$ & 41.47 & 40.18 & 43.20 & 36.74 & 41.77 & 39.55 & 2.59 & 0.37 \\
\hline \multicolumn{9}{|l|}{ Day 29} \\
\hline $\mathrm{C} 16: 0$ & $216.6^{b}$ & $241.9^{\mathrm{a}}$ & $243.6^{\mathrm{a}}$ & $227.2^{\mathrm{ab}}$ & $221.1^{b}$ & $238.3^{\mathrm{ab}}$ & 7.37 & 0.01 \\
\hline C18:0 & $325.2^{\mathrm{d}}$ & $401.9^{\mathrm{ab}}$ & $422.6^{\mathrm{a}}$ & $347.9^{\mathrm{cd}}$ & $363.1^{\mathrm{c}}$ & $375.9^{\mathrm{bc}}$ & 14.22 & $<0.01$ \\
\hline C18:1 cis-9 & $116.4^{\mathrm{b}}$ & $132.9^{\mathrm{a}}$ & $144.3^{\mathrm{a}}$ & $135.7^{\mathrm{a}}$ & $134.8^{\mathrm{a}}$ & $142.9^{\mathrm{a}}$ & 5.20 & $<0.01$ \\
\hline $\mathrm{C} 18: 2$ cis-9, cis-12 & $1,207^{b}$ & $1,423^{\mathrm{a}}$ & $1,473^{\mathrm{a}}$ & $1,234^{b}$ & $1,266^{\mathrm{b}}$ & $1,227^{b}$ & 43.61 & $<0.01$ \\
\hline $\mathrm{C} 18: 3 n-6$ & $8.57^{\mathrm{a}}$ & $4.48^{\mathrm{c}}$ & $1.36^{\mathrm{d}}$ & $7.83^{\mathrm{ab}}$ & $5.98^{\mathrm{bc}}$ & $4.74^{\mathrm{c}}$ & 0.73 & $<0.01$ \\
\hline $\mathrm{C} 18: 3 n-3$ & $21.42^{\mathrm{e}}$ & $145.9^{c}$ & $278.0^{\mathrm{a}}$ & $72.34^{\mathrm{d}}$ & $138.7^{\mathrm{c}}$ & $208.1^{\mathrm{b}}$ & 5.86 & $<0.01$ \\
\hline
\end{tabular}

${ }^{\mathrm{a}-\mathrm{d}}$ Within a row, means without a common superscript differ $(P<0.05)$.

${ }^{1} P$-values for treatment effect.

Means were considered different at a $P$ value of $\leq 0.05$, and a $P$ value of $\leq 0.10$ was considered as a tendency.

\section{RESULTS}

Two animals died due to reasons unrelated to the experimental treatments, 6 animals gave birth during the study, and 1 was a steer. All data from these animals were removed from the study.

\section{Long-Chain Fatty Acids in Plasma}

The main plasma LCFA are presented in Table 3. At the beginning of the experiment (d 0), LCFA were not different among treatments $(P>0.15)$, but after $29 \mathrm{~d}$ of feeding dietary treatments, LCFA profiles were altered $(P<0.05)$. The predominant $n-3$ FA, $\alpha$-linolenic acid (ALA; C18:3 $n$-3), increased from $21.4 \mu \mathrm{g} / \mathrm{mL}$ of plasma with the $0 \%$ Flaxseed diet to 145.9 and $278.0 \mu \mathrm{g} / \mathrm{mL}$ of plasma when 3 and $6 \%$ flaxseed were fed, respectively. Differences $(P>0.05)$ were observed with the protected flaxseed (L-Flaxseed), where ALA concentrations were $72.3,138.7$, and $208.1 \mu \mathrm{g} / \mathrm{mL}$ of plasma for cattle fed 2, 4, and 6\% L-Flaxseed, respectively. Other fatty acids were also affected. The C16:0 and C18:2 n-6 were similar between $0 \%$ Flaxseed and 2, 4, and 6\% LFlaxseed $(P>0.05)$, and C18:0 were similar between $0 \%$ Flaxseed and 2\% L-Flaxseed $(P>0.05)$.

\section{Feedlot Performance and Carcass Characteristics}

Feedlot performance and carcass traits results are reported in Tables 4 and 5, respectively. Flaxseed treatments and $2 \%$ L-Flaxseed did not affect the performance of heifers $(P>0.05)$, and these treatments were not different from the $0 \%$ flaxseed diet. Inclusion of 4 and $6 \%$ L-Flaxseed had a negative impact on performance $(P<$ $0.05)$. Final shrunk body weights for these treatments decreased by 11 and $34 \mathrm{~kg}$, respectively, compared with the control, and similar effects were observed with adjusted final BW, which was decreased by 14.5 and 45.7 $\mathrm{kg}$, respectively, compared with the control. In addition, 4 and $6 \%$ L-Flaxseed had lower ADG $(P<0.01)$ than the control, with 0.07 and $0.21 \mathrm{~kg} / \mathrm{d}$ decreases, respectively. Dry matter intake of 4 and 6\% L-Flaxseed treatments also decreased $(P<0.01)$ compared to the control by 0.49 and $1.5 \mathrm{~kg} / \mathrm{d}$, respectively. Gain-to-feed ratio was unaffected by treatments $(P=0.72)$.

The hot and cold carcass weights were not affected $(P>0.05)$ when flaxseed or $2 \%$ L-Flaxseed was added to the diet, but carcasses resulting from the addition of 4 or $6 \%$ L-Flaxseed were approximately 10 and $30 \mathrm{~kg}$ lighter than those fed the $0 \%$ flaxseed treatment, and they also had a decreased dressing percentage $(P<$ $0.01)$. The LM area increased $(P<0.05)$ in those animals treated with $6 \%$ flaxseed and $2 \%$ L-Flaxseed, decreased when $6 \%$ L-Flaxseed was included $(P<0.05)$, and stayed the same with other treatments $(P>0.05)$. Fat thickness was $1.23 \mathrm{~cm}$ for animals fed the $6 \% \mathrm{~L}-$ Flaxseed treatment, which was significantly lower $(P<$ $0.01)$ than those fed other treatments, which were not different from each other (1.54-cm average, $P>0.05$ ). 
Table 4. Feedlot performance of heifers fed 0,3 , and 6\% ground flaxseed (Flaxseed) or 2, 4, and 6\% of a 1:1 blend of dolomitic lime hydrate and ground flaxseed formed into a prilled matrix (L-Flaxseed)

\begin{tabular}{|c|c|c|c|c|c|c|c|c|}
\hline \multirow[b]{2}{*}{ Item } & \multicolumn{3}{|c|}{ Flaxseed } & \multicolumn{3}{|c|}{ L-Flaxseed } & \multirow[b]{2}{*}{ SEM } & \multirow[b]{2}{*}{$P$-value ${ }^{1}$} \\
\hline & $0 \%$ & $3 \%$ & $6 \%$ & $2 \%$ & $4 \%$ & $6 \%$ & & \\
\hline Initial BW, kg & 346.9 & 345.7 & 342.3 & 346.2 & 347.2 & 346.8 & 6.23 & 0.26 \\
\hline Final $\mathrm{BW}^{2}, \mathrm{~kg}$ & $546.5^{\mathrm{a}}$ & $548.0^{\mathrm{a}}$ & $542.2^{\mathrm{a}}$ & $543.1^{\mathrm{a}}$ & $535.8^{\mathrm{b}}$ & $513.0^{\mathrm{c}}$ & 6.57 & $<0.01$ \\
\hline Adjusted final $\mathrm{BW}^{3}, \mathrm{~kg}$ & $552.3^{\mathrm{a}}$ & $559.8^{\mathrm{a}}$ & $554.9^{\mathrm{a}}$ & $555.1^{\mathrm{a}}$ & $537.8^{\mathrm{b}}$ & $506.6^{\mathrm{c}}$ & 6.42 & $<0.01$ \\
\hline $\mathrm{ADG}^{2}, \mathrm{~kg} / \mathrm{d}$ & $1.31^{\mathrm{a}}$ & $1.33^{\mathrm{a}}$ & $1.32^{\mathrm{a}}$ & $1.30^{\mathrm{a}}$ & $1.24^{\mathrm{b}}$ & $1.10^{\mathrm{c}}$ & 0.035 & $<0.01$ \\
\hline Adjusted $\mathrm{ADG}^{3}, \mathrm{~kg} / \mathrm{d}$ & $1.35^{\mathrm{a}}$ & $1.41^{\mathrm{a}}$ & $1.40^{\mathrm{a}}$ & $1.37^{\mathrm{a}}$ & $1.26^{\mathrm{b}}$ & $1.05^{\mathrm{c}}$ & 0.034 & $<0.01$ \\
\hline DMI, kg/d & $8.93^{\mathrm{a}}$ & $8.82^{\mathrm{a}}$ & $8.79^{\mathrm{a}}$ & $8.89^{\mathrm{a}}$ & $8.44^{\mathrm{b}}$ & $7.43^{\mathrm{c}}$ & 0.160 & $<0.01$ \\
\hline $\mathrm{G}: \mathrm{F}^{2}$ & 0.1470 & 0.1511 & 0.1499 & 0.1458 & 0.1470 & 0.1473 & 0.0011 & 0.72 \\
\hline
\end{tabular}

${ }^{\mathrm{a}-\mathrm{c}}$ Within a row, means without a common superscript differ $(P<0.05)$.

${ }^{1} P$-values for treatment effect.

${ }^{2} \mathrm{BW}$ calculated as gross live $\mathrm{BW} \times 0.96$ (i.e., shrunk BW).

${ }^{3} \mathrm{BW}$ calculated as HCW divided by a common dressed yield of 0.635 .

Table 5. Carcass traits of heifers fed 0,3 , and $6 \%$ ground flaxseed (Flaxseed) or 2, 4, and 6\% of a 1:1 blend of dolomitic lime hydrate and ground flaxseed formed into a prilled matrix (L-Flaxseed)

\begin{tabular}{|c|c|c|c|c|c|c|c|c|}
\hline \multirow[b]{2}{*}{ Item } & \multicolumn{3}{|c|}{ Flaxseed } & \multicolumn{3}{|c|}{ L-Flaxseed } & \multirow[b]{2}{*}{ SEM } & \multirow[b]{2}{*}{$P$-value ${ }^{1}$} \\
\hline & $0 \%$ & $3 \%$ & $6 \%$ & $2 \%$ & $4 \%$ & $6 \%$ & & \\
\hline$\overline{\mathrm{HCW}}, \mathrm{kg}$ & $350.7^{\mathrm{a}}$ & $354.5^{\mathrm{a}}$ & $352.4^{\mathrm{a}}$ & $351.9^{\mathrm{a}}$ & $341.0^{\mathrm{b}}$ & $321.7^{c}$ & 4.09 & $<0.01$ \\
\hline $\mathrm{CCW}^{2}, \mathrm{~kg}$ & $351.5^{\mathrm{a}}$ & $355.3^{\mathrm{a}}$ & $353.0^{\mathrm{a}}$ & $352.8^{\mathrm{a}}$ & $341.9^{\mathrm{b}}$ & $322.3^{\mathrm{c}}$ & 4.09 & $<0.01$ \\
\hline Dressed yield, \% & $64.2^{\mathrm{ab}}$ & $64.9^{\mathrm{a}}$ & $65.0^{\mathrm{a}}$ & $64.9^{\mathrm{a}}$ & $63.7^{\mathrm{b}}$ & $62.7^{\mathrm{c}}$ & 0.239 & $<0.01$ \\
\hline $\mathrm{LM}$ area, $\mathrm{cm}^{2}$ & $87.26^{\mathrm{b}}$ & $88.04^{\mathrm{ab}}$ & $90.02^{\mathrm{a}}$ & $89.79^{\mathrm{a}}$ & $85.09^{\mathrm{bc}}$ & $84.59^{c}$ & 1.04 & $<0.01$ \\
\hline 12th-rib fat thickness, $\mathrm{cm}$ & $1.54^{\mathrm{a}}$ & $1.60^{\mathrm{a}}$ & $1.54^{\mathrm{a}}$ & $1.53^{\mathrm{a}}$ & $1.51^{\mathrm{a}}$ & $1.23^{\mathrm{b}}$ & 0.053 & $<0.01$ \\
\hline $\mathrm{KPH}, \%$ & 2.63 & 2.59 & 2.88 & 2.87 & 2.56 & 2.69 & 2.08 & 0.44 \\
\hline Marbling score ${ }^{3}$ & $493.2^{\mathrm{a}}$ & $498.8^{\mathrm{a}}$ & $490.7^{\mathrm{a}}$ & $490.1^{\mathrm{a}}$ & $496.9^{\mathrm{a}}$ & $448.6^{\mathrm{b}}$ & 12.4 & 0.04 \\
\hline USDA yield grade & $2.73^{\mathrm{a}}$ & $2.76^{\mathrm{a}}$ & $2.62^{\mathrm{a}}$ & $2.57^{\mathrm{ab}}$ & $2.76^{\mathrm{a}}$ & $2.32^{\mathrm{b}}$ & 0.101 & 0.01 \\
\hline Yield grade 1, \% & 5.33 & 5.33 & 9.09 & 9.33 & 8.00 & 18.18 & 3.40 & 0.10 \\
\hline Yield grade 2, \% & 30.67 & 28.00 & 29.87 & 36.00 & 30.67 & 35.06 & 5.42 & 0.85 \\
\hline Yield grade 3, \% & 50.67 & 52.00 & 50.65 & 42.67 & 40.00 & 42.86 & 5.81 & 0.51 \\
\hline Yield grade $4, \%$ & 12.00 & 14.67 & 10.39 & 12.00 & 20.00 & 3.90 & 3.90 & 0.08 \\
\hline Yield grade 5, \% & 1.33 & 0.00 & 0.00 & 0.00 & 1.33 & 0.00 & 0.77 & 0.51 \\
\hline Liver abscesses ${ }^{4}, \%$ & 14.67 & 16.00 & 7.79 & 14.67 & 12.00 & 10.39 & 3.92 & 0.63 \\
\hline $\mathrm{A}^{-}, \%$ & 8.00 & 10.67 & 6.49 & 8.00 & 8.00 & 6.49 & 3.16 & 0.94 \\
\hline $\mathrm{A}, \%$ & 6.67 & 5.33 & 1.30 & 6.67 & 4.00 & 3.90 & 2.57 & 0.60 \\
\hline $\mathrm{A}^{+}, \%$ & 0.00 & 0.00 & 0.00 & 0.00 & 0.00 & 0.00 & & \\
\hline Prime, $\%$ & 4.00 & 1.33 & 9.09 & 5.33 & 2.67 & 1.30 & 2.26 & 0.12 \\
\hline Premium Choice 5 , \% & $44.0^{\mathrm{a}}$ & $49.3^{\mathrm{a}}$ & $36.4^{\mathrm{a}}$ & $38.7^{\mathrm{a}}$ & $37.3^{\mathrm{a}}$ & $16.9^{\mathrm{b}}$ & 5.64 & $<0.01$ \\
\hline Choice, $\%$ & 42.7 & 41.3 & 40.3 & 36.0 & 42.7 & 58.4 & 5.79 & 0.10 \\
\hline Select, \% & 8.00 & 6.67 & 14.29 & 16.00 & 13.33 & 18.18 & 4.12 & 0.14 \\
\hline Low grade $5, \%$ & 1.33 & 1.33 & 0.00 & 1.33 & 0.00 & 0.00 & 0.95 & 0.69 \\
\hline No roll, \% & 0.00 & 0.00 & 0.00 & 0.00 & 1.33 & 2.60 & 0.94 & 0.23 \\
\hline Other grade, $\%$ & 0.00 & 0.00 & 0.00 & 2.67 & 2.67 & 2.60 & 1.35 & 0.38 \\
\hline
\end{tabular}

${ }^{\mathrm{a}-\mathrm{c}}$ Within a row, means without a common superscript differ $(P<0.05)$.

${ }^{1} P$-values for treatment effect.

${ }^{2} \mathrm{CCW}=$ cold carcass weight.

${ }^{3}$ Marbling score 400 to $499=$ small.

${ }^{4}$ Liver Abscesses: $\mathrm{A}^{-}=1$ or 2 small abscesses. $\mathrm{A}=2$ to 4 well organized abscesses. $\mathrm{A}^{+}=1$ or more large abscesses along with inflammation (Liver Abscess Technical Information AI 6288; Elanco Animal Health, Greenfield, IN).

${ }^{5}$ Premium Choice $=$ marbling score was greater than 500 and less than 700, thus qualifying carcass for upper two-thirds of the USDA Choice quality grade. Low grade $=$ animals with advanced bone maturity, thus carcasses were classified as USDA Commercial. 
Table 6. Long-chain fatty acid composition for loin steaks derived from heifers fed 0,3 , and $6 \%$ ground flaxseed (Flaxseed) or 2, 4, and 6\% of a 1:1 blend of dolomitic lime hydrate and ground flaxseed formed into a prilled matrix (L-Flaxseed) expressed as milligrams per gram of wet tissue

\begin{tabular}{|c|c|c|c|c|c|c|c|c|}
\hline \multirow[b]{2}{*}{ Fatty acid, mg/g } & \multicolumn{3}{|c|}{ Flaxseed } & \multicolumn{3}{|c|}{ L-Flaxseed } & \multirow[b]{2}{*}{ SEM } & \multirow[b]{2}{*}{$P$-value } \\
\hline & $0 \%$ & $3 \%$ & $6 \%$ & $2 \%$ & $4 \%$ & $6 \%$ & & \\
\hline C10:0 & 0.041 & 0.035 & 0.040 & 0.037 & 0.041 & 0.039 & 0.01 & 0.81 \\
\hline C12:0 & 0.048 & 0.044 & 0.048 & 0.045 & 0.048 & 0.044 & 0.01 & 0.96 \\
\hline $\mathrm{C} 14: 0$ & 2.11 & 1.89 & 2.18 & 2.00 & 2.15 & 1.89 & 0.21 & 0.82 \\
\hline C14:1 & 0.619 & 0.572 & 0.638 & 0.585 & 0.620 & 0.503 & 0.06 & 0.64 \\
\hline $\mathrm{C} 15: 0$ & 0.292 & 0.258 & 0.287 & 0.262 & 0.260 & 0.222 & 0.03 & 0.55 \\
\hline C16:0 & 18.00 & 16.51 & 17.96 & 17.34 & 17.78 & 16.00 & 1.56 & 0.90 \\
\hline C16:1 & 1.41 & 1.17 & 1.14 & 1.20 & 1.28 & 1.28 & 0.29 & 0.90 \\
\hline C17:0 & 0.80 & 0.73 & 0.75 & 0.72 & 0.71 & 0.56 & 0.07 & 0.30 \\
\hline $\mathrm{C} 17: 1$ & $0.71^{\mathrm{a}}$ & $0.62^{\mathrm{ab}}$ & $0.60^{\mathrm{ab}}$ & $0.64^{\mathrm{ab}}$ & $0.54^{\mathrm{b}}$ & $0.46^{\mathrm{b}}$ & 0.05 & 0.02 \\
\hline C18:0 & 8.11 & 8.17 & 8.70 & 7.87 & 8.44 & 7.81 & 0.75 & 0.95 \\
\hline C18:1 trans -9 & 1.60 & 1.57 & 1.65 & 1.96 & 2.11 & 1.84 & 0.20 & 0.29 \\
\hline C18:1 cis-9 & 19.60 & 20.57 & 20.21 & 20.50 & 16.66 & 15.33 & 3.51 & 0.75 \\
\hline C18:2 trans -9, trans 12 & 0.031 & 0.034 & 0.039 & 0.029 & 0.034 & 0.035 & 0.00 & 0.45 \\
\hline $\mathrm{C} 18: 2$ cis- 9, cis -12 & 1.22 & 1.09 & 1.13 & 0.95 & 1.09 & 1.24 & 0.29 & 0.87 \\
\hline $\mathrm{C} 20: 0$ & $0.043^{\mathrm{b}}$ & $0.047^{\mathrm{b}}$ & $0.065^{\mathrm{a}}$ & $0.044^{\mathrm{b}}$ & $0.047^{\mathrm{b}}$ & $0.048^{\mathrm{b}}$ & 0.01 & 0.05 \\
\hline $\mathrm{C} 18: 3 n-3$ & $0.173^{\mathrm{e}}$ & $0.482^{\mathrm{c}}$ & $0.743^{\mathrm{a}}$ & $0.288^{\mathrm{d}}$ & $0.433^{\mathrm{c}}$ & $0.592^{\mathrm{b}}$ & 0.04 & $<0.01$ \\
\hline $\mathrm{C} 20: 1$ & 0.142 & 0.144 & 0.164 & 0.151 & 0.153 & 0.167 & 0.02 & 0.83 \\
\hline $\mathrm{C} 20: 2$ & 0.077 & 0.090 & 0.084 & 0.070 & 0.069 & 0.079 & 0.01 & 0.34 \\
\hline $\mathrm{C} 20: 3 n-6$ & 0.224 & 0.222 & 0.203 & 0.203 & 0.182 & 0.213 & 0.02 & 0.32 \\
\hline $\mathrm{C} 20: 3 n-3 / \mathrm{C} 22: 1 n-9$ & $0.551^{\mathrm{a}}$ & $0.544^{\mathrm{a}}$ & $0.479^{b}$ & $0.517^{\mathrm{ab}}$ & $0.486^{\mathrm{b}}$ & $0.506^{\mathrm{ab}}$ & 0.02 & 0.03 \\
\hline Total fatty acids & 55.81 & 54.80 & 57.15 & 55.39 & 53.14 & 48.88 & 5.98 & 0.92 \\
\hline
\end{tabular}

a-e Within a row, means without a common superscript $\operatorname{differ}(P<0.05)$

${ }^{1} P$-values for treatment effect.

Marbling score and yield grade were unaffected by the addition of flaxseed or 2 and 4\% L-Flaxseed but were lower $(P<0.05)$ in the $6 \%$ L-Flaxseed group. Animals with marbling scores greater than 500 and less than 700 , thus qualifying carcasses for the upper two-thirds of the USDA Choice quality grade (Premium Choice), were lower $(P<0.05)$ in the $6 \%$ L-Flaxseed group. Other carcass traits were unaffected $(P \geq 0.08)$ by treatment.

\section{Long-Chain Fatty Acids in Loins}

Long-chain fatty acid compositions for loin steaks are reported in Tables 6 (concentration, $\mathrm{mg} / \mathrm{g}$ ) and 7 (as percentage of total fatty acids). The ALA concentration increased $(P<0.01)$ when flaxseed or L-Flaxseed were added to the diets. The addition of 3 and $6 \%$ flaxseed resulted in ALA concentrations in meat that were 2.8- and 4.3-fold higher than those in animals fed the control diet, respectively. Addition of 2, 4, and 6\% LFlaxseed increased ALA concentrations by 0.7-, 1.5-, and 2.4-fold, respectively. This positive effect was also reflected when it was expressed as a percentage of the total fat $(P<0.01)$. The trans $\mathrm{C} 18: 1 n-9$ concentration was increased with the inclusion of L-Flaxseed in the $\operatorname{diet}(P=0.002)$. The proportions of trans $\mathrm{C} 18: 2 n-6$ and $\mathrm{C} 20: 2$ in total fat were increased with the inclusion of flaxseed and L-Flaxseed in the $\operatorname{diet}(P<0.02)$. Finally, the concentration and proportion of C20:0 increased with the inclusion of flaxseed and L-Flaxseed in the diet $(P<0.01)$. Other LCFA concentrations or proportions were not affected $(P>0.1)$.

\section{DISCUSSION}

Adipose tissue from feedlot cattle normally contains low concentrations of PUFA and, more specifically, low concentrations of $n-3$ FA, compared with adipose tissue from grazing cattle (Rule et al., 2002; Montgomery et al., 2008). Low concentrations are due in part to extensive biohydrogenation of PUFA by ruminal bacteria. Previous experiments have shown that increasing the concentration of PUFA via the addition of flaxseed in the diet is an effective way to increase the plasma $n-3$ FA concentrations (Farran et al., 2008; Zachut et al., 2010; Corazzin et al., 2012; He et al., 2012). Unfortunately, feeding flaxseed without a protection against rumen microorganism biohydrogenation is an inefficient process (Scollan et al., 2001). Using ground flaxseed embedded within a protective matrix of dolomitic lime hydrate in this study yielded 
Table 7. Long-chain fatty acid composition for loin steaks derived from heifers fed 0,3 , and $6 \%$ ground flaxseed (Flaxseed) or 2, 4, and 6\% of a 1:1 blend of dolomitic lime hydrate and ground flaxseed formed into a prilled matrix (L-Flaxseed) expressed as a percentage of total identified fatty acid

\begin{tabular}{|c|c|c|c|c|c|c|c|c|}
\hline \multirow[b]{2}{*}{ Fatty acid, $\%$} & \multicolumn{3}{|c|}{ Flaxseed } & \multicolumn{3}{|c|}{ L-Flaxseed } & \multirow[b]{2}{*}{ SEM } & \multirow[b]{2}{*}{$P$-value } \\
\hline & 0 & $3 \%$ & $6 \%$ & $2 \%$ & $4 \%$ & $6 \%$ & & \\
\hline C10:0 & 0.08 & 0.07 & 0.08 & 0.07 & 0.08 & 0.09 & 0.01 & 0.11 \\
\hline C12:0 & 0.09 & 0.08 & 0.09 & 0.08 & 0.10 & 0.10 & 0.01 & 0.37 \\
\hline C14:0 & 4.07 & 3.74 & 4.13 & 3.80 & 4.29 & 4.19 & 0.33 & 0.46 \\
\hline C14:1 & 1.19 & 1.14 & 1.20 & 1.13 & 1.24 & 1.10 & 0.10 & 0.77 \\
\hline C15:0 & 0.54 & 0.51 & 0.54 & 0.49 & 0.53 & 0.51 & 0.04 & 0.85 \\
\hline C16:0 & 34.35 & 33.90 & 35.04 & 33.13 & 35.96 & 35.71 & 2.64 & 0.88 \\
\hline C16:1 & 2.46 & 2.10 & 1.85 & 2.13 & 2.38 & 2.34 & 0.41 & 0.52 \\
\hline C17:0 & 1.47 & 1.46 & 1.44 & 1.33 & 1.42 & 1.28 & 0.11 & 0.61 \\
\hline $\mathrm{C} 17: 1$ & 1.33 & 1.32 & 1.24 & 1.21 & 1.21 & 1.10 & 0.11 & 0.48 \\
\hline C18:0 & 15.45 & 16.53 & 17.38 & 15.20 & 17.02 & 17.67 & 1.32 & 0.36 \\
\hline C18:1 trans-9 & $3.03^{b}$ & $3.20^{\mathrm{b}}$ & $3.15^{\mathrm{b}}$ & $3.69^{\mathrm{ab}}$ & $4.07^{\mathrm{a}}$ & $4.32^{\mathrm{a}}$ & 0.33 & 0.00 \\
\hline C18:1 cis-9 & 31.21 & 30.34 & 28.11 & 33.11 & 26.43 & 24.44 & 4.49 & 0.49 \\
\hline C18:2 trans- 9, trans -12 & $0.06^{\mathrm{b}}$ & $0.07^{\mathrm{ab}}$ & $0.08^{\mathrm{a}}$ & $0.05^{\mathrm{b}}$ & $0.07^{\mathrm{ab}}$ & $0.08^{\mathrm{a}}$ & 0.01 & 0.02 \\
\hline $\mathrm{C} 18: 2$ cis-9,cis-12 & 2.03 & 2.05 & 1.84 & 1.93 & 2.16 & 2.80 & 0.56 & 0.50 \\
\hline C20:0 & $0.08^{c}$ & $0.09^{b c}$ & $0.13^{\mathrm{a}}$ & $0.09^{b c}$ & $0.09^{b c}$ & $0.11^{\mathrm{b}}$ & 0.01 & $<0.01$ \\
\hline $\mathrm{C} 18: 3 n-3$ & $0.36^{\mathrm{c}}$ & $1.02^{\mathrm{b}}$ & $1.56^{\mathrm{a}}$ & $0.57^{\mathrm{c}}$ & $0.92^{\mathrm{b}}$ & $1.45^{\mathrm{a}}$ & 0.11 & $<0.01$ \\
\hline C20:1 & 0.29 & 0.30 & 0.34 & 0.29 & 0.32 & 0.42 & 0.04 & 0.06 \\
\hline C20:2 & $0.14^{\mathrm{b}}$ & $0.18^{\mathrm{a}}$ & $0.16^{\mathrm{ab}}$ & $0.14^{\mathrm{b}}$ & $0.14^{\mathrm{b}}$ & $0.18^{\mathrm{a}}$ & 0.01 & 0.02 \\
\hline $\mathrm{C} 20: 3 n-6$ & 0.49 & 0.50 & 0.46 & 0.44 & 0.40 & 0.58 & 0.07 & 0.41 \\
\hline $\mathrm{C} 20: 3 n-3 / \mathrm{C} 22: 1 n-9$ & 1.26 & 1.37 & 1.17 & 1.12 & 1.13 & 1.50 & 0.19 & 0.58 \\
\hline
\end{tabular}

${ }^{\mathrm{a}-\mathrm{c}}$ Within a row, means without a common superscript differ $(P<0.05)$.

${ }^{1} P$-values for treatment effect.

an increase of $62.6 \mu \mathrm{g}$ of ALA $/ \mathrm{mL}$ of plasma for every $1 \%$ of protected flaxseed added to the diet, which was a $46 \%$ improvement over results obtained with unprotected ground flaxseed (Fig. 1). This improvement is far less than the 5.7-fold improvement shown when

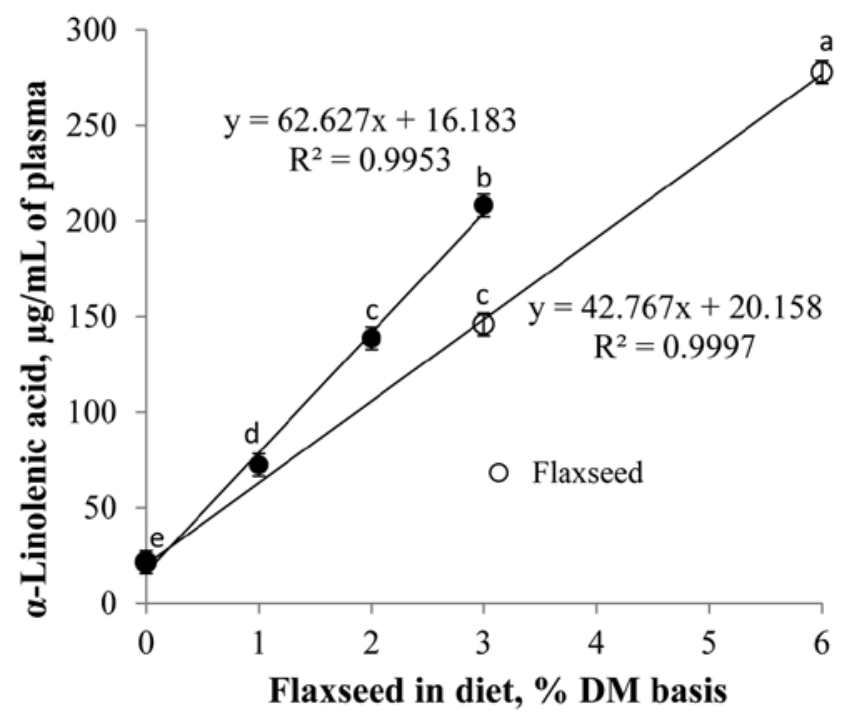

Figure 1. $\alpha$-Linolenic acid in plasma of heifers fed 0,3 , and $6 \%$ ground flaxseed (Flaxseed) or 2, 4, and 6\% of a 1:1 blend of dolomitic lime hydrate and ground flaxseed formed into a prilled matrix (L-Flaxseed). Means without a common superscript letter are different $(P<0.05)$. Treatment effect, $P<0.001$; SEM, 5.86 . flaxseed oil is infused directly into the proximal duodenum (thus avoiding biohydrogenation), as was reported by Scislowski et al. (2005). The use of L-Flaxseed may, however, be more practical than using a protein gel to isolated flaxseed oil (Heguy et al., 2006) and more acceptable to consumers than formaldehyde-treated products (Ashes et al., 1992; Kronberg et al., 2007)

Meat sample analyses confirmed our earlier observation in plasma profiles after $29 \mathrm{~d}$ on feed. Increasing PUFA via addition of flaxseed in the diet was reflected by higher concentrations of $n-3$ FA, particularly ALA, and the rate at which this FA was incorporated into meat tissues was $47 \%$ greater when ground flaxseed was protected with dolomitic lime hydrate (Fig. 2). The ALA concentrations in meat from animals receiving $6 \%$ L-Flaxseed in their diets was $23 \%$ greater than in animals fed diets containing 3\% unprotected flaxseed. It is important to consider that these 2 treatments supply equal amounts of flaxseed (3\%), which demonstrates the effectiveness of our method (co-prilling ground flaxseed with dolomitic lime hydrate) to protect LCFA against biohydrogenation.

Our first goal in this study was to protect LCFA against the action of microorganisms without adversely affecting animal performance. Previous studies where flaxseed was used as the source of LCFA 


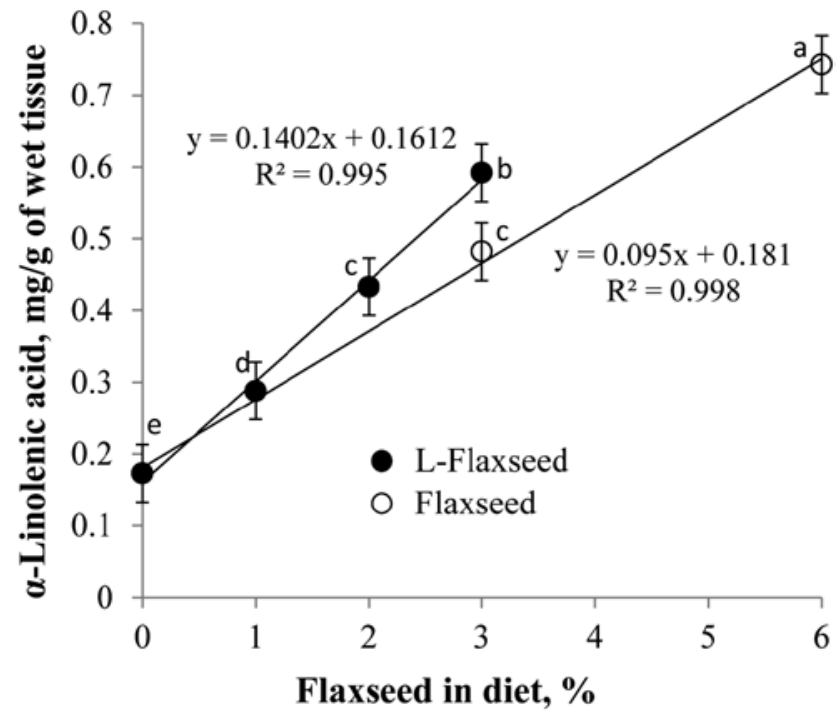

Figure 2. $\alpha$-Linolenic acid for loin steaks derived from heifers fed 0,3 , and $6 \%$ ground flaxseed (Flaxseed) or 2, 4, and $6 \%$ of a 1:1 blend of dolomitic lime hydrate and ground flaxseed formed into a prilled matrix (L-Flaxseed). Means without a common superscript letter are different $(P<0.05)$. Treatment effect, $P<0.001$; SEM, 0.04 .

showed no negative effects on animal performance when finishing diets contained 5\% ground flaxseed (Drouillard et al., 2004). One study even reported improvement in feedlot performance when $8 \%$ flaxseed was included, reflected by no change in DMI but greater ADG and improved efficiency (Kronberg et al., 2007). In the present study, we observed no adverse effect of unprotected flaxseed (Flaxseed treatments) on feedlot performance but a negative effect when flaxseed was protected with a matrix of dolomitic lime hydrate (L-Flaxseed treatment), specifically with 4 and $6 \%$ inclusion rates, which decreased DMI by 0.49 and $1.50 \mathrm{~kg} / \mathrm{d}$, respectively. Decreases in DMI resulted in commensurate changes in ADG and final BW of the animals (Table 4). The exception was the treatment that included $2 \%$ L-Flaxseed, which had no adverse effects on feedlot performance.

The negative effects of 4 and $6 \%$ L-Flaxseed treatments were also observed in carcass traits: $\mathrm{HCW}$, dressing percentage, and LM area decreased, presumably due to poorer intake and ADG during the feedlot phase. The addition of $2 \%$ L-Flaxseed resulted in carcass measurements comparable to the 0,3 , and $6 \%$ flaxseed treatments, which could imply that this level of L-Flaxseed could be a feasible alternative, but unfortunately the improvement in ALA concentration in meat is lower than the concentration obtained with the unprotected flaxseed.

In earlier studies, $\mathrm{Ca}(\mathrm{OH})_{2}$ and $\mathrm{Mg}(\mathrm{OH})_{2}$, which are the primary components of dolomitic lime hydrate, were evaluated as rumen buffers in cows fed highconcentrate/low-roughage diets (Thomas and Emery,
1969; Thomas et al., 1984) to prevent milk fat depression syndrome in dairy cows. These studies revealed a capacity for the hydrates to buffer the rumen, but a negative effect on voluntary DMI was also observed. More recently, Oddy et al. (2003) compared the effects of $\mathrm{CaCO}_{3}$ and $\mathrm{Ca}(\mathrm{OH})_{2}$ additions to feedlot steer diets on the deposition of intramuscular fat. There were no differences among treatments with respect to fat deposition, but feeding the dolomitic lime hydrate decreased DMI, ultimately depressing growth rate. These results are in agreement with our observations, although the specific cause is not presently known.

\section{Implications}

This study indicates that a matrix consisting of dolomitic lime hydrate is an effective barrier to ruminal biohydrogenation of unsaturated fats. This technology also may have application for protecting a broad range of nutrients that are otherwise susceptible to premature degradation by ruminal microbes. The adverse effects of lime hydrates on feed intake may limit application of the technology to use with ingredients that are fed in relatively small quantities. Further studies are needed to explain why DMI is depressed when hydroxide forms of $\mathrm{Mg}$ and $\mathrm{Ca}$ are used in cattle feeding without adverse effect.

\section{LITERATURE CITED}

Alvarado-Gilis, C. A., C. C. Aperce, K. A. Miller, C. L. Van BibberKrueger, D. Klamfoth, and J. S. Drouillard. 2015. Protection of polyunsaturated fatty acids against ruminal biohydrogenation: Pilot experiments for three approaches. J. Anim. Sci. 93:3101-3109.

Ashes, J. R., B. D. Siebert, S. K. Gulati, A. Z. Cuthbertson, and T. W. Scott. 1992. Incorporation of $n-3$ fatty acids of fish oil into tissue and serum lipids of ruminants. Lipids 27:629-631.

Corazzin, M., S. Bovolenta, A. Sepulcri, and E. Piasentier. 2012. Effect of whole linseed addition on meat production and quality of Italian Simmental and Holstein young bulls. Meat Sci. 90:99-105.

Daniel, C. R., A. J. Cross, C. Koebnick, and R. Sinha. 2011. Trends in meat consumption in the United States. Public Health Nutr. 14:575-583.

Drouillard, J. S., M. A. Seyfert, E. J. Good, E. R. Loe, B. Depenbusch, and R. Daubert. 2004. Flaxseed for finishing beef cattle: Effects on animal performance, carcass quality, and meat composition In: Proc. 60th. Flax Institute, Fargo, ND. p. 108-117.

Farran, T. B., C. D. Reinhardt, D. A. Blasi, J. E. Minton, T. H. Elsasser, J. J. Higgins, and J. S. Drouillard. 2008. Source of dietary lipid may modify the immune response in stressed feeder cattle. J. Anim. Sci. 86:1382-1394.

He, M. L., T. A. McAllister, J. P. Kastelic, P. S. Mir, J. L. Aalhus, M. E. R. Dugan, N. Aldai, and J. J. McKinnon. 2012. Feeding flaxseed in grass hay and barley silage diets to beef cows increases alpha-linolenic acid and its biohydrogenation intermediates in subcutaneous fat. J. Anim. Sci. 90:592-604. 
Heguy, J. M., S. O. Juchem, E. J. DePeters, M. Rosenberg, J. E. P. Santos, and S. J. Taylor. 2006. Whey protein gel composites of soybean and linseed oils as a dietary method to modify the unsaturated fatty acid composition of milk lipids. Anim. Feed Sci. Technol. 131:370-388.

Kronberg, S. L., E. J. Scholljegerdes, G. Barceló-Coblijn, and E. J. Murphy. 2007. Flaxseed treatments to reduce biohydrogenation of $\alpha$-linolenic acid by rumen microbes in cattle. Lipids 42:1105-1111.

Montgomery, S. P., J. S. Drouillard, T. G. Nagaraja, E. C. Titgemeyer, and J. J. Sindt. 2008. Effects of supplemental fat source on nutrient digestion and ruminal fermentation in steers. J. Anim. Sci. 86:640-650.

Oddy, V. H., S. H. Bird, and L. G. Walker. 2003. Evaluation of calcium and canola oil in the diet of feedlot steers. Aust. J. Exp. Agric. 43:459-465.

Papanikolaou, Y., J. Brooks, C. Reider, and V. L. Fulgoni, III. 2014. U.S. adults are not meeting recommended levels for fish and omega-3 fatty acid intake: Results of an analysis using observational data from NHANES 2003-2008. Nutr. J. 13:31.

Rule, D. C., K. S. Broughton, S. M. Shellito, and G. Maiorano. 2002. Comparison of muscle fatty acid profiles and cholesterol concentrations of bison, beef cattle, elk, and chicken. J. Anim. Sci. 80:1202-1211.
Scislowski V., D. Bauchart, D. Gruffat, P. M. Laplaud, and D. Durand. 2005. Effects of dietary $n-6$ or $n-3$ polyunsaturated fatty acids protected or not protected against ruminal hydrogenation on plasma lipids and their susceptibility to peroxidation in fattening steers. J. Anim. Sci. 83:2162-2174.

Scollan, N. D., M. S. Dhanoa, N. J. Choi, W. J. Maeng, M. Enser, and J. D. Wood. 2001. Biohydrogenation and digestion of long chain fatty acids in steers fed on different sources of lipid. J. Agric. Sci. 136:345-355.

Sukhija, P. S., and D. L. Palmquist. 1988. Rapid method for determination of total fatty acid content and composition of feedstuffs and feces. J. Agric. Food Chem. 36:1202-1206.

Thomas, J. W., and R. S. Emery. 1969. Effects of sodium bicarbonate, magnesium oxide, and calcium hydroxide on milk fat secretion. J. Dairy Sci. 52:60-63.

Thomas, J. W., R. S. Emery, J. K. Breaux, and J. S. Liesman. 1984. Response of milking cows fed a high concentrate, low roughage diet plus sodium bicarbonate, magnesium oxide, or magnesium hydroxide. J. Dairy Sci. 67:2532-2545.

Zachut, M., A. Arieli, H. Lehrer, L. Livshitz, S. Yakoby, and U. Moallem. 2010. Effects of increased supplementation of $n-3$ fatty acids to transition dairy cows on performance and fatty acid profile in plasma, adipose tissue, and milk fat. J. Dairy Sci. 93:5877-5889. 
Reproduced with permission of the copyright owner. Further reproduction prohibited without permission. 